\title{
PEMBUATAN KUE KERING BERBASIS KEARIFAN LOKAL DI KECAMAAN BRONDONG-LAMONGAN (KAJIAN RESPON PELATIHAN)
}

\author{
Oleh: \\ Mauren Gita Miranti ${ }^{1}$, Nugrahani Astuti ${ }^{2}$, Sri Handajani ${ }^{3}$ \\ 1,2,3Fakultas Teknik, Jurusan Pendidikan Kesejahteraan Keluarga,Unesa \\ ${ }^{1}$ maurenmiranti@unesa.ac.id
}

\begin{abstract}
Abstrak
Salah satu indikator untuk mengukur keberhasilan kegiatan pelatihan dapat dilihat dari respon peserta terhadap pelaksanaan pelatihan. Kegiatan pelatihan pembuatan kue kering berbasis kearifan lokal ini merupakan kegiatan pengabdian berupa jasa. Evaluasi dilakukan untuk mengetahui efektivitas dan efisiensi pelatihan. Hasil survey dapat dipergunakan sebagai acuan peningkatan kualitas penyelenggaraan pelatihan pada kegiatan pengabdian kedepannya. Tujuan pengabdian ini adalah meningkatkan pemahaman ibu-ibu dalam menggunakan, memanfaatkan dan mengembangan produk berbasis bahan lokal, meningkatkan pemahaman mengenai keamanan pangan dan penggunaan bahan tambahan pangan, serta meningkatkan pengetahuan mengenai manajemen usaha kue kering. Metode yang digunakan untuk memperoleh respon peserta pelatihan adalah metode kuesioner. Berdasarkan analisis angket respon yang disebarkan, diperoleh hasil sebesar $84,1 \%$ merasa puas terhadap pelatihan yang dilakukan, hal ini dapat dilihat dari materi pelatihan, instrukur, sarana/prasarana, serta pelaksanaan pelatihan yang mendapatkan respon positif. Sehingga dapat disimpulkan peserta memperoleh wawasan untuk memanfaatkan sumber pangan lokal dalam pembuatan kue kering.
\end{abstract}

Kata Kunci: Pelatihan, Kue Kering, Kearifan Lokal, Pangan Lokal

\begin{abstract}
One of the indicators to measure the success of training activities can be seen from the participant's response to the training implementation. The training activities of patstries based on local wisdom is a service activity. Evaluation is conducted to determine the effectiveness and efficiency of the training. The results of the survey can be used as a reference to improve the quality of training in the futures. The purpose of this activity is to improve the understanding of woman in using, utilizing and developing food based on local ingredients, improving the understanding of food safety and the use of food additives, and increasing knowledge of food business management. The method used to obtain trainee response is questionnaire method. Based on the analysis the results obtained $84.1 \%$ are satisfied with the training, this can be seen from the training materials, instructors, facilities / infrastructure, and the implementation of training that get positive response. So it can be concluded that the participants gain insight to utilize local food in making the pastries.
\end{abstract}

Keywords: Training, Pastries, Local Wisdom, Local Food

\section{PENDAHULUAN}

Sedayu lawas merupakan desa di kecamatan Brondong, Kabupaten Lamongan Jawa Timur, yang terletak di daerah pantai utara Jawa Timur. Struktur mata pencariannya adalah petani sebanyak 1.763 orang, untuk sektor jasa/perdagangan ada 912 orang sedangkan yang bergerak di sektor industri ada 3216 orang. Ada sebanyak 30 PNS (Pegawai Negeri sipil) dan 15 warga Desa Sendayu lawas yang menjadi anggota TNI/POLRI. 145 orang menjadi guru
3 orang menjadi dokter, 5 orang bidan dan 6 orang mantri kesehatan (sumber: monograf Desa Sedayu Lawas). Lebih dari 600 warga memilki perahu, baik dioperasikan sendiri maupun disewakan.

lbu-ibu Anggota Aisyiyah desa Sedayulawas memilki aktifitas keseharian selain belajar agama, mereka juga merupakan garda depan di masyarakat dalam mengajak dan mencontohkan bagaimana melaksanakan ajaran agama/syariat Islam dalam kehidupan sehari-hari di masyarakat sekitarnya. 
Kegiatan lain yang tengah dikembangkan saat ini adalah mengembangkan ekonomi kemasyarakatan. Kelompok ini berharap, selain dapat memberikan ilmu agama, mereka juga berharap untuk bisa meningkatkan kesejahteraan keluarga melalui peningkatan ekonomi kemasyarakatan yang berbasis industri rumah tangga.

Upaya tersebut diatas sudah dirintis melalui beberapa keterampilan membuat olahan ikan bagi ibu-ibu anggota Aisyiyah, yang kemudian membagikan pengetahuan dan keterampilannya pada warga sekitar, diantara olahan ikan yang telah dilatihkan adalah pembuatan abon ikan dan keripik ikan. Desa Sedayu Lawas selain potensial akan ikan, baik ikan laut, ikan air payau maupun tawar, juga banyak memilki pontensi bahan pangan lokal lain yang belum dioptimalkan pemanfaatannya, diantaranya adalah rumput laut dan daun kelor yang banyak tumbuh dipekarangan. Daun kelor memiliki potensi sebagai bahan subtitusi dalam pembuatan produk kue kering (Aina, 2014; Kholis dan Hadi, 2010; Qoniah, 2014; Kaloso, 2010), selain dapat menambah nilai gizi juga karena dapa digunakan sebagai pewarna alami (Aminah, 2015; Krisnadi, 2010). Hal inilah yang mendorong ibu-bu ingin mengoptimalkan potensi yang ada (kearifan lokal) untuk dapat lebih menunjang ekonomi dan kesejahteraan masyarakatnya (Ariani, 2013). Karena dengan menggali dan mengembangkan kearifan lokal, kemiskinan tidak hanya dapat dikurangi (relieving) tetapi juga dapat dihindari (preventing) karena lestarinya sumberdaya bagi generai berikutnya (Soehani, 2005; Cahyanto, 2012). Untuk itu mereka berharap agar dapat meningkatkan peranannya dalam upaya meningkatkan ekonomi keluarrga melalui ketrampilan pengolahan makanan. Salah satu peluang usaha yang mereka bidik adalah usaha kue kering yang memanfaatkan potensi kearifan lokal masyarakat.

Kue kering adalah salah satu makanan ringan yang banyak digemari masyarakat
(Okaviana, dkk, 2017). Kue kering dibidik karena jenis olahan ini selain membuatnya tidak terlalu sulit, alat yang digunakan dalam pengolahanpun mudah diupayakan dan relatif murah, artinya untuk memulai usaha kue kering tidak membutuhkan modal yang banyak (Kusuma, dkk, 2016). Kue kering merupakan pruduk yang awet, menurut Silfia (2012) dalam keadaan terbuka kue kering dapat bertahan sampai 4 bulan. Sifatnya yang tahan lama dan dapat dimodivikasi sesuai dengan kekhasan daerah, sangat mendukung dalam hal pengembagan wisata daerah sebagai makanan khas oleh-oleh Lamongan, Desa Sedayu lawas khususnya yang potensial ikan dan hasil perkebunan lainnya.

Sasaran dalam kegiatan pengabdian ini adalah pelaku Industri Kecil dan Menengah dan Ibu rumah tangga di Desa Sedayulawas Kecamatan Brondong-Lamongan. Sesuai dengan permasalahan yang ada maka target yang ingin dihasilkan dari kegiatan pengabdian masyarakat ini adalah memiliki pengetahuan dan keterampilan membuat aneka kue kering berbsis kearifan lokal. Adapun luaran yang dihasilkan dalam kegiatan pengabdian masyarakat ini adalah berupa buku resep dan artikel ilmiah. Menumenu yang tersusun dalam buku resep tersebut disesuaikan dengan bahan dasar yang tersedia dilingkungan desa Sedayulawas.

\section{METODE PELAKSANAAN}

Metode kegiatan yang dilakukan dalam pengabdian kepada masyarakat ini adalah dalam bentuk ceramah dan presentasi, serta tanya jawab. Untuk memberikan kesempatan bagi peserta dan memantapkan pengetahuan peserta, maka dilakukan demonstrasi dan pelatihan pembuatan kue kering. Lebih rinci terkait metode dalam pelatihan ini dapat dilihat pada Gambar 1 berikut: 


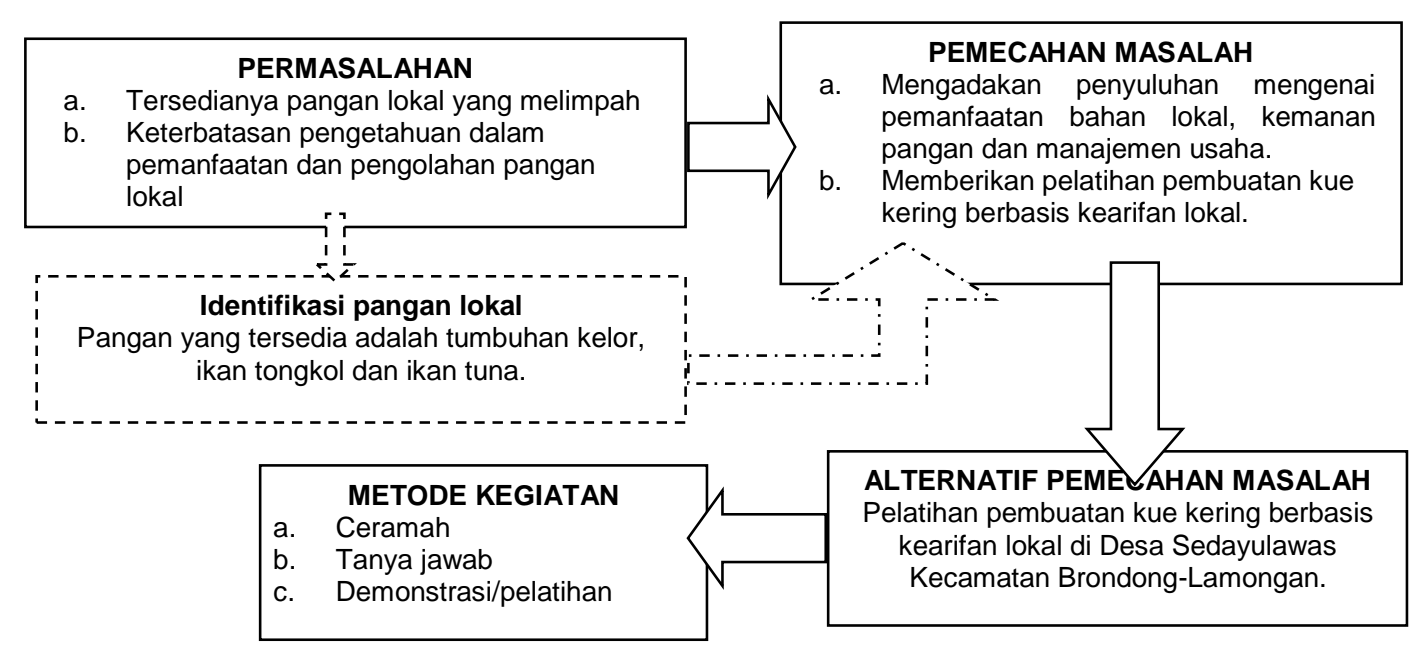

Gambar 1. Alur Kerangka Pemecahan Masalah

Kegiatan pengabdian ini dilakukan dengan tahap-tahap sebagai berikut:

1. Menyampaikan materi pelatihan mengenai penetapan harga jual produk, pengetahuan bahan makanan,pengetahuan peralatan boga, serta sanitasi dan higiene melalui ceramah dan tanya jawab.

2. Demonstrasi dan pelatihan pembuatan produk. Setelah penyampaian materi dan diskusi, pelatihan ini juga diselenggaran dengan mengadakan demonstrasi dan praktek pembuatan kue kering berbasis kearifan pangan lokal. Peserta pelatihan tidak hanya mengamati, tetapi juga iku membuat produk sesuai dengan standar resep yang diberikan. Adapun produk yang dibuat adalah soes kering tuna, kue kacang kelor, pastel kering isi abon ikan tongkol, dan pia kelor isi kacang hijau.

\section{HASIL DAN PEMBAHASAN}

\section{Pelaksanaan Pelatihan}

Pelatihan pembuatan kue kering berbasis kearifan lokal dilakukan pada tanggal 30 September 2017 di Desa Sedayulawas Brondong-Lamongan. Peserta kegiatan adalah pelaku Industri Kecil dan Menengah dan lbu rumah tangga yang tergabung dalam komunitas Ibu-ibu Aisyiyah. Kegiatan bertepan di TK Aisyiyah Bustanul Athfal sebanyak 54 peserta dengan range usia 2960 an. Pelaksanaan kegiaan dilaksanakan di aula MI Muhammadiah pada pukul 10.02 14.20 wib.

Tim PKM disambut oleh Kepala Sekolah TK Aisyiyah Bustanul Athfal yang merangkap sebagai ketua Aisyiyah Cabang Sedayulawas, yaitu lbu Aris . Kegiatan pelatihan dibuka dengan pebacaan ayat suci Al-Quran oleh salah satu ibu Aisyiyah dan kemudian dilanjutkan dengan sambutan oleh pimpinan Aisyiyah Kecamatan Brondol dan dari ketua jurusan PKK FT Unesa Dr. Rita Ismawati, S. Pd., M. Pd. Pelaksanaan kegiatan ini dilakukan oleh 3 (tiga) orang tim pengabdi, dengan pokok bahasan yang disampaikan mengenai: penentuan harga jual produk, pengetahuan bahan makanan, pengetahuan perlatan dapur, sanitasi dan hygiene, latihan pembuatan kue kering, serta evaluasi produk dan kegiatan yang telah disusun.Materi terkait pelatihan disampaikan oleh Ibu Nugrahani Astuti, S. Pd., M. Pd. sedangkan persiapan bahan dan alat serta praktikum dilakukan oleh Ibu Dr. Sri Hndajani, S. Pd., M. Pd. dan Ibu Mauren Gita Miranti, S. Pd., M. Pd. namun tetap dibantu juga oleh lbu Nugrahani Astuti, S. Pd., M. Pd.

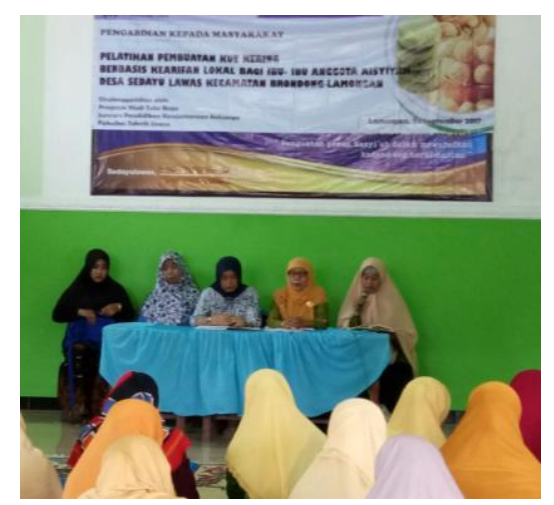

Gambar 2. Kegiatan Pembukaan dan Pemberian Materi Pelatihan 
Peserta pelatihan dengan antusias mendengarkan penyampaian materi yang diberikan oleh Ibu Nugrahani Astuti, S. Pd., M. Pd., hal ini terlihat dari banyaknya pertanyaan yang diajukan oleh peserta mengenai langkah-langkah pembuatan kue kering dan pengetahuan bahan. Setelah penyampaian materi, kergiatan berikutnya adalah peraktikum pembuatan kue kering. Pesera sebanyak 50 lebih dibagi menjadi 4 (empat) kelompok, yaitu: kelompok 1 membuat pia kelor isi kacang hijau, kelompok 2 membuat pastel kering isi abon, kelompok 3 membuat soes abon tuna, dan kelompok 4 membuat kue kacang kelor.

Setiap peserta dibebaskan untuk memilih produk mana yang ingin ia buat dan ia pelajari. Pembuatan produk diawasi dan dibimbing oleh instruktur. Pembuatan pia kelor dibimbing oleh bu Nugrahani, pembuatan pastel kering isi abon di bimbing oleh bu Mauren, pembuatan kue kacang kelor dibimbing oleh bu Sri Handajani, dan pembuatan soes kering abon ikan dibimbing oleh bu Nugrahi dan bu Mauren.

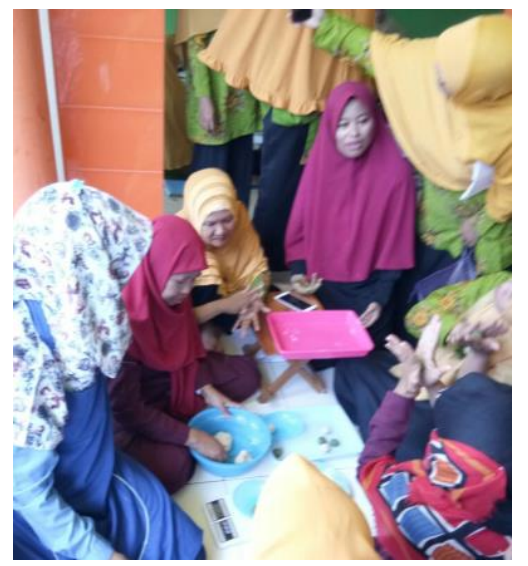

Gambar 3. Kegiatan Pelatihan Pembuatan Kue Kering

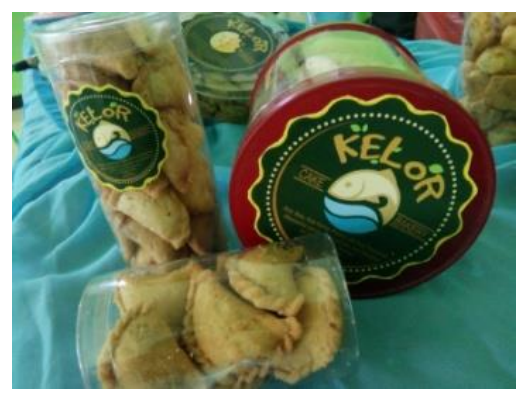

Gambar 4. Contoh Produk

Pelatihan (kue kacang kelor, pastel kering tuna, sus kering tuna)

Program pengabdian kepada masyarakat berupa pelatihan pembuatan kue kering berbasis kearifan lokal yang sudah dilaksanakan ini diharapkan dapat menambah pengetahuan, keterampilan dan memotifasi peserta untuk berwirausaha dengan ide-ide yang diberikan. Selain dapat dijadikan penghasilan tambahan, berwirausaha makanann dengan bahan khas daerah juga dapat dijadikan oleh-oleh khas daerah tersebut. Hasil pelatihan akan bermanfaat bagi sekolah, lembaga Aisyiyah, dan bagi setiap individu masing-masing.

Tidak terdapat kendala yang berarti didalam pelaksanaan pengabdian berupa pelatihan. Bahan yang digunakan adalah bahan lokal yang mudah didapat, peralatan yang dipakai sudah cukup baik secara kuantitas dan kualitas, di tambah dengan perangkat lain seperti modul/ materi yang tersaji dengan bahasa yang mudah dipahami, serta instruktur yang kompeten dibidangnya.

\section{Tanggapan Peserta Pelatihan}

Berdasarkan analisis angket evaluasi responden yang disebarkan kepada seluruh peserta pelatihan setelah selesai melakukan pelatihan memberikan hasil sebagai berikut: $84,1 \%$ memberikan respon positif terhadap kegiatan pengabdian ini. Mereka berharap pelatihan sejenis dapat dilanjutkan untuk guru lainnya yang belum mendapatkan kesempatan mengikuti pelatihan ini. Analisis lebih mendalam terhadap butir-butir instrumen diperoleh gambaran seperti pada Gambar 5.

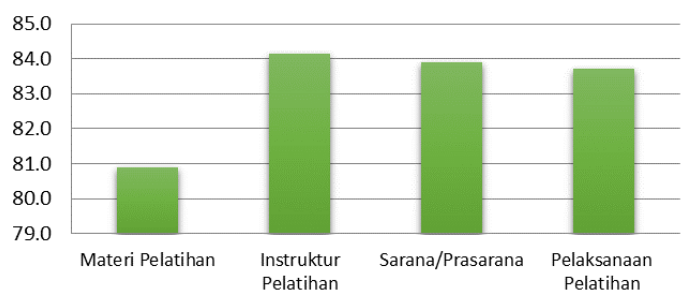

Gambar 5. Hasil respon pelatihan

Dari kegiatan pelatihan, terdapat empat indikator yang akan dievaluasi, yaitu 1) materi pelatihan, 2) intruktur pelatihan, 3) sarana/prasarana, dan 4) pelaksanaan pelatihan secara keseluruhan. Secara umum pegiatan pelatihan mendapatkan repon yang sangat baik, yaitu dengan rata-rata $84,1 \%$. Peserta berharap pelatihan sejenis dapat dilanjutkan untuk masyarakat khususnya pelaku industri rumahan yang belum mendapatkan kesempatan untuk mengikuti pelatihan ini.

Analisis lebih mendalam terhadap butirbutir instrumen diperoleh gambaran sebagai 
berikut; sebanyak $80,9 \%$ peserta pelatihan merasa sangat puas terhadap materi yang disampaikan/diberikan pada saat pelatihan. Hal ini karena peserta belum pernah mendapatkan materi pelatihan dalam pengolahan pangan berbasis kearifan lokal sebelumnya. Peserta juga merasa terbantu sekali dengan resep-resep kue berbasis pangan lokal yang diberikan oleh pemateri, selain karena dapat menjadi inspirasi dalam pengolahan makanan, juga dapat menjadi ide dalam berwirausaha. Materi dilengkapi dengan modul dan aneka resep yang mudah untuk diaplikasikan dalam rumah tanga.

Kepuasan terhadap instrukur memiliki respon yang sangat baik, yaitu sebanyak $84,1 \%$ peserta merasa sangat puas terhadap instrukur. Hal ini dapat dilihat dari pengetahuan yang dimiliki oleh instrukur sangat memadai dalam membimbing pelatihan, instrukur bekerja sesuai prosedur, serta menjelaskan materi dan teori secara jelas, memberikan contoh nyata, serta memperhatikan k3 (kesehatan dan keselamatan kerja). Dari segi dukungan fasilitas, sebanyak $83,9 \%$ peserta merasa sangat puas terhadap sarana/prasarana yang instruktur sediakan dalam menunjang pelatihan. Bahan yang digunakan dalam pelatihan selain menggunakan bahan lokal, yaitu daun kelor, ikan tuna, dan tongkol, bahan lainnya pun menggunakan bahan yang mudah didapatkan. Sedangkan dari kegiatan pelatihan pelaksanaan sebanyak $83,7 \%$ peserta merasa sangat puas. Hal ini karena isi pelatihan berhubungan dengan usaha yang dijalani peserta, isi pelatihan mendukung pengetahuan baru, teknik dan resep yang didapatkan dari pelatihan tidak didapatkan dari buku/pelatihan lainnya, isi pelatihan mudah untuk dikuasai, serta bimbingan yang diberikan dalam pelatihan mudah dimengerti.

Sebagian peserta pelatihan menyatakan agar kegiatan pelatihan ini dapat dilakukan kembali dilain waktu, dan berharap bahwa Desa Sedayulawas dapat menjadi desa binaan dalam hal kewirausahaan bidang pengolahan makanan. Penjabaran detail dari hasil wawancara dang angket respon yang disebar kepada peserta pelatihan, dapat dipaparkan bahwasannya kegiatan ini telah memberikan kontribusi yang sangat positif kepada pelaku Industri Kecil dan Menengah dan Ibu rumah tangga yang tergabung dalam komunitas Ibu-ibu Aisyiyah, yaitu: peserta memperoleh wawasan untuk memanfaatkan sumber pangan lokal dalam pembuatan kue kering.

\section{SIMPULAN DAN SARAN}

Program pelatihan dapat diselenggarakan dengan baik dan berjalan dengan lancar sesuai dengan rencana kegiatan yang telah disusun meskipun belum semua peserta pendampingan menguasai dengan baik materi yang disampaikan. Kegiatan ini mendapat sambutan sangat baik terbukti dengan keaktifan peserta mengikuti pelatihan dengan ikut berpartisipasi dalam pelatihan. Dari hasil evaluasi didperoleh informasi bahwa pemahaman peserta mendapatkan pemahaman mengenai penggunakaan, pemanfaatan dan pengembangan kue kering berbasis pangan lokal, pemahaman mengenai keamanan pangan dan penggunaan bahan tambahan pangan pun bertambah, memperoleh pengalaman mengenai pengolahan kue kering berbasis kearifan lokal, dan peserta semakin paham mengenai penentuan harga jual produk makanan.

\section{DAFTAR PUSTAKA}

Aina, Q, (2014), Pengaruh Penambahan Tepung Daun Kelor (Moringa oleifera) dan Jenis Lemak Terhadap Hasil Jadi Rich Biskuit, EJournal Boga, Vol 03, No 3: Surabaya.

Aminah, Ayarifah. Dkk. 2015. Kandungan Nutrisi dan Sifat Fungsional Tanaman Kelor (Moringa oleifera). Buletin Pertanian Perkotaan Volume 5 Nomor 2, 2015.

Ariani, Mewa, dkk. 2013. Kajian Strategi Pengembangan Diversifikasi Pangan Lokal: Laporan Kegiatan Kajian IsuIsu Aktual Kebijakan Pembangunan Pertanian 2013. Pusat Sosial Ekonomi Dan Kebijakan Pertanian Badan Penelitian Dan Pengembangan Pertanian.

Cahyanto, Sugeng Setya, dkk. 2012. Penguatan Kearifan Lokal Sebagai Solusi Permasalahan Ketahanan Pangan Nasional. Prosiding the $4^{\text {th }}$ Internastional Conference on Indonesian Studies: "Unity, Diversity and Future". 
Kasolo, et al, (2010), Phytochemicals and Uses of Moringa oleifera Leaves in Ugandan Rural Communities, Journal of Medical Plant Research. Vol. 4 (9) : 753-757.

Kholis, Nur dan Fariz Hadi. 2010. Pengujian Bioassay Biskuit Balita Yang Disuplementasi Konsentrat Protein Daun Kelor (Moringa oleifera) Pada Model Tikus Malnutrisi. Jurnal Teknologi Pertanian Vol. 11 No. 3 (Desember 2010) 144-151.

Krisnadi, (2010), Kelor Super Nutrisi. Pusat Informasi dan Pengembangan Tanaman Kelor Indonesia, Blora.

Kusuma, Dewi Fitri, dkk. 2016. Pembuatan Cookies Dengan Penambahan Tepung Daun Kelor (Moringa oleifera) Pada Berbagai Suhu Pemanggangan. Arikel Program Studi Teknologi Pangan, Fakultas Teknik Universitas Pasundan Bandung. Diakses pada 09 Oktober 2017.
Oktaviana, Anik Sholekah, dkk. 2017. Kadar Protein, Daya Kembang, Dan Organoleptik Cookies Dengan Substitusi Tepung Mocaf Dan Tepung Pisang Kepok. Jurnal Pangan dan Gizi Volume 7 No. 2 tahun 2017 ISSN: 2086-6429.

Qoniah, Eka Wahyu. 2014. Uji Kadar Protein Dan Uji Organoleptik Biskuit Dengan Ratio Tepung Terigu Dan Tepung Daun Kelor (Moringa oleifera) Yang Ditambahkan Sari Buah Nanas (Ananas comosus). Naskah Publikasi Program Studi Pendidikan Biologi Fakultas Keguruan dan IImu Pendidikan Universias Muhammadiyah Surakarta.

Silfia. 2012. Pengaruh Subtitusi Tepung Pisang Terhadap Mutu Kue Kering. Jurnal Libang Industri, Volume 2 No. 1 Juni 2012: 43-49.

Soejani, M. 2005. Krisis Kearifan Kita. Kompas, Kamis 20 Oktober 2005. 